\title{
Prolonged PR Interval by ECG Finding
}

National Cancer Institute

\section{Source}

National Cancer Institute. Prolonged PR Interval by ECG Finding. NCI Thesaurus. Code C62247.

An electrocardiographic finding of a PR interval of more than 0.20 seconds in adults. 